\title{
Karel Steenbrink
}

Catholics in Independent Indonesia: 1945-2010. Verhandelingen van het Koninklijk Instituut voor Taal-, Land en Volkenkunde, vol. 298. Leiden; Boston : Brill, 2015. Pp. $\mathrm{xx}+636 . \mathrm{Hb}, \$ 249,192$ euros.

Two main theses strike the reader of Karel Steenbrink's latest installment on the development of the Indonesian Catholic community: first, despite constituting a small minority, Catholics have played an active role in the construction of a democratic Indonesia; second, and a corollary, this Catholic community has achieved a transition from a missionary church into a fully Indonesian one. Instrumental and representative of both projects, the Jesuits occupy a central place in Steenbrink's account.

The capstone of a trilogy (the earlier titles were published by KITLV Press), Steenbrink divides this book into two parts: "National Issues" and "Regional Surveys." The former is arranged thematically, while the latter provides a series of case studies illustrating the cultural plurality of Catholic communities in Indonesia. In the first chapter, Steenbrink situates this diffuse ecclesial community within the post-independence debates between two poles, the Islamic ethico-religious ideal of shariah in the form of constitutionalized law, and the inclusive principles of Pancasila as a sort of civil religion. Indonesia, as an exception to the general rule that post-war liberation movements of Muslim-majority nations tended to result in direct state control of religious institutions, opted for the latter. A key figure in articulating the value of Pancasila from a Catholic perspective is Albertus Soegijapranata, S.J., the first indigenous bishop of Indonesia. While Soegijapranata makes a distinct impression on this civil matter, his influence on the national church is immense. For instance, within Steenbrink's appendix, the reader can find a document in Dutch in which the bishop advises another Jesuit, Jo Dijkstra, to persuade newly independent Papua to enter the Indonesian state (534-39). This political activism is a notable trait for many Jesuits in the Indonesian context, and without firm adherence to any political ideology. For some, this entailed a prominent place in the public sphere; for example, the Gregorianeducated philosopher Nicholas Driyarkara occasionally advised the dictatorial regime of Sukarno, while his successor Franz Magnis-Suseno targeted Soeharto's government for criticism over wide-scale corruption and also campaigned against Marxism. Dick Hartoko and the Jesuit brother, Sindhunata, mediate the public discourse through the oldest periodical, Basis. And yet others took more covert measures, like Joop Beek, who counseled political resistance networks. 
Although Steenbrink credits various religious orders for the expansion of the Catholic Church in Indonesia, it is apparent that the Society of Jesus, as the "oldest order in modern Indonesia" and as "a strongly Javanese order" (95), residing in the political hub of the nation, produces the greatest impact. In Chapter 3 , Steenbrink employs a demographic model to outline and detail the respective size and scope of each religious order in Indonesia. As he observes, the Jesuits are the most numerous and due to evolving ecclesial dynamics in recent decades, the Society still extend its influence in manifold ways through its range of ministries. For one, the Kongregasi Maria (the Sodality of Our Lady), a lay group established by the Belgian Jan Leunis, S.J., in the sixteenth century, became a social force in parishes where the Society works, past development and current. Education has become a critical forum for engaging the broader Indonesian population. Referring to Canisius College in Jakarta and De Britto College of Yogyakarta, Steenbrink repeats on several occasions that these institutions have become the most prestigious schools for sons of the liberal Muslim elite of Indonesia. In turn - though not detailed in this book-this Jesuit model of education can be traced to have influence on the national education system as well. In Chapter 5, Steenbrink sketches these details for other Jesuit ministries in health care and development initiatives. Of particular interest for those in the field of Jesuit studies is the final, thematic chapter, which effectively serves as a survey of the leading Catholic public intellectuals during this period, with most of the attention falling upon Jesuits, both native- and foreign-born.

After the first part, which carries the bulk of this historical narrative, Steenbrink concentrates upon regional case studies to portray the multicultural dimensions of the Indonesian church. Eight in total, these foci allow Steenbrink to illustrate specific tensions and trends for Indonesian Catholics across this diverse archipelago. In several of these cases, he observes the influence of the Latin American model of "base communities" taking root in Indonesia, a development difficult to imagine without the international network and presence of the Jesuits. While the Dutch province in particular has exerted its influence upon these developments, one can detect internal tensions with some regions, for example in Timor, where there had been a much stronger Portuguese Jesuit presence.

To be sure, as Steenbrink judiciously explains, such tensions are not solely of an ecclesial variety, as Catholics have been both objects and agents of sectarian violence with their Muslim and Protestant neighbors. Yet for a growing church more integrated to the local landscape and history, pilgrimage has become a means of navigating some of these tensions, especially with respects to sites of martyrdom. In this regard Bagus Laksana, himself an Indonesian Jesuit, has written what can be a helpful companion piece to Steenbrink's 
book: Muslim and Catholic Pilgrimage Practices: Explorations through Java (Burlington, VT: Ashgate, 2014), offering a comparative theological study of Catholic and Muslim pilgrimage practices.

Having updated much earlier scholarship, Steenbrink has also introduced much of this material into English for the first time while doing so in a more comprehensive manner than previous works on the subject. A valuable reference book for any specialist, this account is especially fruitful being read from a Jesuit perspective. While the accessibility and breadth of his work is commendable, the book does at times suffer from a lack of narrative flow and editorial clarity in its structure, as at times the author is repetitive. With the particular focus on internal dynamics, some individuals, like Thomas Michel, S.J., a figure with immense importance for the global church in its attempts at interreligious dialogue with Muslims, receive too little attention. Nevertheless, Steenbrink lends his intimate knowledge of the subject, presenting a dynamic example of the Asian church becoming more confident in its social milieu that will be a useful resource for those interested for years to come.

\section{Michael VanZandt Collins}

Boston College

vanzandt@bc.edu

DOI 10.1163/22141332-00301005-19 